\title{
Money Makes the EU Go Round: The Objective Foundations of Conflict in the Council of Ministers*
}

\author{
STEFANIE BAILER, ${ }^{1}$ MIKKO MATTILA ${ }^{2}$ and GERALD SCHNEIDER ${ }^{3}$ \\ ${ }^{1}$ ETH Zürich. ${ }^{2}$ University of Helsinki. ${ }^{3}$ University of Konstanz
}

\begin{abstract}
Many examinations of the dimensions of conflict in the European Union Council of Ministers focus on the ideological roots of contestation in the EU. This article examines the extent to which structural attributes of the Member States explain the conflict within the Council of Ministers in general as well as in selected policy domains (agriculture, fisheries, environment, economic affairs). Drawing on the political economy literature of legislative decision-making, a multilevel analysis shows that country-level redistributive interests shape the interactions considerably and in some of the policy domains that are examined in more detail. The impact of ideological variables like the left-right positioning of the Member State governments remains inconsistent and marginal in this analysis.
\end{abstract}

\section{Introduction}

According to Laswell's (1936) dictum, 'politics is who gets what, when, where and how'. Strangely enough, the notion that political decision-making is largely a redistributive conflict between contending social and economic forces rarely makes it into the study of legislative decision-making in the European Union. This applies particularly to analyses of Council voting and is in considerable contrast to analyses of the EU budgetary process (Aksoy, 2010; Carrubba, 1997; Kandogan, 2000) and, to some extent, of intergovernmental bargaining within the European Council. In the latter domain, one key theoretical approach - liberal intergovernmentalism - maintains that domestic economic interests shape the bargaining position of the Member States. We examine, based on a political economy framework, whether this hypothesis is also valid for day-to-day decision-making in the intergovernmental legislative EU actor, the Council of Ministers. Some studies of Council decision-making have explored, in contrast to this materialist interpretation, the extent to which ideological conflict shapes the interactions between the Member States, showing that partisan preferences are helpful in predicting aggregate voting patterns in the Council of Ministers (Hagemann and Høyland, 2008).

This article takes issue with the ideological interpretation of intergovernmental decision-making and examines whether the opposition to a majoritarian trend in the

\footnotetext{
* Earlier versions of this article have been presented at the 2011 ECPR General Conference in Reykjavik, the 2011 PEIO conference in Zürich, the 2010 ECPR Conference on EU Politics in Porto, the 2010 APSA Meeting in Washington, DC, as well as seminars at the University of Basel, the Bavarian Permanent Representation in Brussels, the CSCI Institute of Public Goods and Policies in Madrid and the universities of Mannheim and Milan. We would like to thank Christoph Waldmeier, Michael Surber and Annette Aigner for the preparation of the data set and the audiences for comments. Further information on the empirical analysis can be found in a web appendix that is available from the homepage of this journal.
} 
Council reflects key economic interests of the Member States. When a proposal reaches the final stage of formal decision-making, governments can show their discontent through negative votes and abstentions. However, they are typically not able to block the legislation because the Presidency has ascertained that enough positive votes are behind the proposal. Thus, expressing one's opposition to a legislative decision should primarily be understood as a signal to domestic stakeholders and other EU level actors. We contend that executives are juggling between the interests of the median voter and the wishes of powerful clientelistic groups. Governments typically give in to private interests if the decisionmaking process is too arcane for the public or if special interest lobbying predominates within a specific policy sector. The activities of such 'distributional coalitions' (Olson, 1982) become especially influential in policy areas heavily influenced by EU financial contributions or EU regulations. In our analysis, agriculture and fisheries constitute policy areas that are financially attractive for powerful lobbies. We contend more generally, and based on Zimmer et al. (2005), that the losers of decision-making in the Council will be more likely to voice their discontent to the respective domestic actors. The expected losers are the rich Member States, which are much more interested in initiatives to deregulate markets than in the redistributive gains they might possibly achieve through EU legislation. We assume, in other words, that rich Member States use legislative politics to buy the support of the less privileged members and that they signal opposition to projects they consider to be too costly or detrimental to their own population.

To avoid an aggregation bias in our analyses, we conduct multilevel logistic regressions of the chances of Member State opposition to a proposal. Our study moves beyond the extant work through its distinction of different policy sectors, which allows us to offer the first fine-grained analysis of how sector-specific interests influence Council decisionmaking. The empirical tests lend support to what we call the 'median voter' and 'special interest' hypotheses. Member State governments carefully balance general welfare considerations and clientelistic pressure when voting in the Council. The cleavages between the rich and the poor Member States and between the contributors to and the beneficiaries of the EU budget indicate that Council decision-making reflects the divergent economic status of the Member States and that governments respond to these differences in expected ways.

The interests of distributional coalitions, on the other hand, become apparent in almost all of the four sub-councils (agriculture, fishery, environment, economic affairs) that we study and especially in such a highly distributive arena as agricultural policy-making. The empirical tests show further that ideological factors have no systematic and strong influence on the number of rejections; partisanship is thus mostly irrelevant for deliberations in the Council. This suggests that the study of Council voting and possibly other arenas of EU decision-making should focus more on redistributive issues. We acknowledge, however, that our results from the analyses of specific sub-councils apply only to the Council decisions that we studied. Further examinations are needed on areas such as justice and home or foreign affairs.

\section{Conflict Dimensions in the EU Council of Ministers}

\section{Correlates of Council Decision-Making}

This article develops a political economy framework to understand conflict within the Council of Ministers. The extant literature has focused on geographical, ideological and 
economic interests as key factors that shape the deliberations within this intergovernmental legislative actor. In light of the different theoretical concepts, data sets and time frames used in the literature, it is not surprising that the current explanations of the core cleavages within the Council diverge so much.

Examinations that rely on the voting records of the Council establish that either geographical divisions or the left-right conflict structure the deliberations between the Member States. Both Hagemann (2007) and Mattila (2009) identify the left-right cleavage as a dimension of conflict within the Council. Hagemann and Høyland (2008) reach a similar conclusion. However, their study does not control for the possible impact that other conflict dimensions might have. Hagemann and De Clerck-Sachsse (2007b) additionally contend that the eastern enlargements have not affected decision making in the Council. Mattila (2009), however, shows that the division between the northern and the southern Member States continues to be a major cleavage. Using the Council voting records since the first Eastern enlargement, he also finds a weak conflict between the 'old' and 'new' Member States (Mattila, 2009). Furthermore, Hosli et al. (2011) demonstrate, through an analysis of the votes between 2004 and 2006, that the effect of partisan preferences is only discernible for the old Member States with left-leaning governments.

Interview-based studies have also shown that geographically close Member States are more likely to vote similarly in the Council. This is particularly the case for some early studies that have used the 'Decision Making in the European Union' (DEU) data set. Although Kaeding and Selck (2005) could not establish a clear cleavage, they uncovered at least a north-south division - a finding that Thomson et al. (2004) confirm and to which they add a regulatory versus market-based dimension. ${ }^{1}$ Using the extended DEU data set, Thomson (2009) found a new, albeit weak, cleavage between the old and new Member States in the post-2004 EU reflecting the preference of the new members to obtain more subsidies. Yet the DEU data set was also the empirical basis for Zimmer et al. (2005), which argued that the conflict between net beneficiaries and net contributors to the EU budget to be of primary importance instead of the north-south dimension. Further analyses by Bailer (2011) confirm this finding and show that rather domestic interests than partisanship explains the conflict dimensions.

Studies using survey data to identify the communication patterns of Brussels-based diplomats find the north-south division rather than diverse ideological dimensions to be relevant (Elgström et al., 2002; Naurin and Lindahl, 2008). A north-south divide and, after the enlargements, an east-west cleavage was also established by Veen's (2011) analysis of EU governments' policy platforms.

We believe that the lack of consensus in studies on the core cleavages within the Council is due to at least three theoretical and methodological problems apart from the usage of incompatible data sets. First, we believe that geographical patterns of coalitionbuilding cannot offer a convincing causal mechanism as to why Member States have a similar voting profile in the Council. In other words, geography offers correlations but not explanations. A second and similar problem besets partisanship theories. One should, in our view, first demonstrate whether it is a joint ideological position rather than a converging economic or social structure that binds governments together. Although there might be

\footnotetext{
${ }^{1}$ Note that the latter study does not represent the conflict space adequately because of the inclusion of the status quo of the included pieces of legislation in the calculation of the conflict dimensions.
} 
a strong association between ideology and voting behaviour in the Council, partisanship might be an endogenous concept for which we first have to determine whether or not it exerts an independent effect at all. Third, we argue that many Council studies suffer from the problem of over-aggregation. Researchers have often tried to establish patterns of decision-making across all arenas and across all institutional peculiarities simultaneously. However, if decision-making patterns vary across policies, such examinations cannot unearth what really happens in the Council. A related problem of aggregation bias besets both structural and partisan explanations. If we lump votes on proposals within a specific time period or a policy sector together, important proposal-level influences might cancel each other out.

\section{The Political Economy of Council Decision-Making}

To address these overlapping challenges, we develop a two-step argument that links economic characteristics and the features of particular sectors to Member State behaviour in the Council. Our theoretical argument is based on the rich literature initiated by Stigler (1971), Peltzman (1976) and Hillman (1989) on the political economy of regulation. According to the generalization of this approach by Grossman and Helpman (1996), governments balance the interests of often conflicting special interest groups, while bearing a cost for implementing an inefficient policy that stems from its accountability to the general electorate. This theory suggests that Member State delegates will give in to the lobbying attempts of relevant clientelistic economic and social groups in order to receive their support. However, strategic politicians will also consider the interests of the electorate as concessions to powerful lobbies create a burden on the median voter. The resulting balancing act implies that government behaviour in the Council reflects both the general economic interests of a country as well as the importance that its government attributes to powerful lobbies.

To start with the economic interests of a Member State, we draw on the aforementioned studies suggesting that countries in southern and eastern Europe behave differently than the older Member States in western Europe (Hosli et al., 2011; Kaeding and Selck, 2005). We argue in line with Zimmer et al. (2005) that these geographical patterns mask different socioeconomic preferences and that there is a strong conflict between the richer and the poor economies. This cleavage puts the net contributors and the net beneficiaries of the EU budget at loggerheads with each other, and translates into a conflict between the competitive members and the less competitive ones.

Studies on the budgetary process (for example, Kauppi and Widgrén, 2004) suggest that richer Member States largely mount the bill for the integration project. In return, they expect policies that are not too costly for them. This logrolling logic is, in our view, one of the reasons as to why a 'culture of consensus' (Heisenberg, 2005) supposedly governs Council interactions (Schneider, 2008). ${ }^{2}$ For example, Aksoy (2012), but also König and Junge (2009), show that states trade votes frequently in the Council, especially in the presence of qualified majority hurdles and multidimensional decision-making spaces. Finally, when a proposal reaches the final voting stage, the President of the Council has

${ }^{2}$ There is an increasing number of studies that explore the conditions of logrolling in the EU. See especially Aksoy ( 2010; 2012); Crombez (2000). 
ensured that a majority of the Member States support it. There are, in other words, strong procedural reasons as to why extensive disagreements should be rare. ${ }^{3}$

The alleged 'culture of consensus' and the logrolls and procedures that maintain it do not work perfectly as the richer Member States might consider certain legislative projects to be too costly and wasteful in comparison to the benefits their economies can derive from the overall integration project. Hence, governments of the economically more successful Member States can use the last voting stage as a mechanism through which they can signal their discontent to their domestic stakeholders, although neither the 'no' votes nor the abstentions will change the final outcome. ${ }^{4}$ Thus, the vote trading logic still holds and the proposal gets adopted. Yet, scratching on the surface of the culture of consensus through a dissenting opinion or abstention allows governments to demonstrate that they cared about domestic stakeholder interests. We therefore expect that the economically strong and competitive states are the ones that voice their opposition more frequently than the EU net beneficiaries. They will do so under the influence of their domestic principals - be it the electorate or specialized interest groups. The logrolls that govern Council interaction are thus imperfect and, the cleavage in the bargaining positions identified by Zimmer et al. (2005) between the beneficiaries and the contributors to the EU budget should also manifest itself in the voting records of the Council. In other words, redistribution is a means to appease the economically weak members of the organization, and governments in the strong EU economies will occasionally use legislative decisions to signal to their domestic stakeholders that they have at least tried to prevent a costly development.

H1: The rich and competitive Member States as well as the net contributors are more likely to oppose legislation in the Council of Ministers.

Government decision-making not only reflects the general economic and financial interests of the Member States, but, as we argued above, also the power of sectoral lobbies. Clientelistic deals are common in the Council because the electorate is usually not well informed about Council deliberations as these negotiations are conducted mostly away from the public scrutiny. Specialized interest groups, conversely, often possess the organizational prerequisites and other resources to follow legislation more closely and to lobby government representatives directly. Therefore, negative votes and abstentions in the Council will be a signal to which mainly domestic interest groups pay some attention.

Our hypothesis that Member States will give in to powerful domestic sectors draws upon a distinguished research tradition. While Kau and Rubin (1979) reject the contention that economic interests alone explain congressional voting behaviour, Peltzman (1984) demonstrates empirically how party and ideology variables play a smaller role when constituent interests are more appropriately accounted for. The socioeconomic characteristics of voting districts have often played a decisive role in the United States Congress, as, for instance, Magee et al. (1989) and many others have shown. Attempts to translate

\footnotetext{
${ }^{3}$ Note that the formal literature disagrees over the role of institutions on the efficiency of vote trading. Shepsle and Weingast (1981) maintain that unanimity increases the economic imperfections of democratic decision-making if the benefits outweigh the tax cost of the project. Assuming the opposite of tax cost exceeding the benefits, Baron (1991) perceives higher majority hurdles as a means to overcome the inefficiencies associated with redistributive politics.

${ }^{4}$ Opposing governments could also use this mechanism to commit themselves in the future to a fiscally more prudent stance. However, we cannot test this alternative hypothesis through the cross-sectional research design introduced below. We are grateful for an anonymous reviewer who alerted us to this alternative mechanism.
} 
such findings into the setting of the EU largely failed because of the obvious differences between a supranational international governmental organization and American democracy (Schuknecht, 1992). There is, however, sufficient evidence from the Member States (for example, Stratmann and Bauer 2002; Schneider et al., 2007) showing that parliamentarians or government actors give in to the wishes of economic interest groups. Hence, the relative importance of an economic sector within a Member State should increase the chance that it votes against the rest of the Member States. Given the general lack of interest among citizens towards EU matters and the often seemingly technical nature of EU decisions, we assume that special interest groups are more likely to take note of a demonstrative abstention or a 'no' vote of their national delegate than the average citizen.

As Moravcsik (1998) maintains, economic interests remain stable over time and will not be affected by partisan changes. It is well known that producer interests have disproportionate influence in political decision-making in general (Olson, 1965) and in EU decision-making (Zimmer et al., 2005) in particular as producers can organize themselves much better than the much larger consumer interests. If we compare the different economic sectors, agriculture and fisheries should possess such a collective action advantage. Franchino and Rahming (2003), for instance, show that measures in favour of the fishing industry, like the quota of fish to be caught in the North Sea, depend on the support of the national governments for such measures in comparison to their environmental preferences, while the left-right orientation does not matter. Specialized interests possess sufficient political clout to motivate their government to signal opposition to EU legislation publicly. The disproportional influence that some industries have in some Member States, including car manufacturing in Germany (Bailer, 2011) or the Spanish fishing industry (Lequesne, 2000), strongly suggests that governments are sensitive to the wishes of strong industries. They might thus be inclined to signal their frustration over a policy outcome through a signal to the domestic constituent that they tried unsuccessfully to prevent a certain decision from being made.

H2: The risk of a negative vote grows with the relative importance that an economic sector has within a Member State.

The second step in our inquiry is to test whether similar relationships also play out within specific policy sectors. We believe, as discussed earlier, that the lack of many studies to establish a clear link between partisanship and economic variables in the Council is due to the high level of aggregation in which the voting records of the Member States are compared. Zimmer et al. (2005) show that for specific Councils more than two-thirds of the variance in Member State preferences can be explained. Ministers accordingly know fairly precisely what the positions of the Member States are and what sort of interests the other delegates represent. To put it differently, we suspect that the economic structure also influences the deliberations in some sub-councils.

In the empirical section we analyze the Member State voting records in three highly redistributive policy areas: agriculture, fisheries and economic affairs. In such policy arenas, the distributive argument by Shepsle and Weingast (1987) for congressional committees should hold to some extent. Stakeholders with the most pronounced economic incentive should have a particularly strong interest in the final decision in such parliamentary sub-arenas. We expect, to take up the Olsonian argument once again, that states with a large agricultural or fisheries sector are what Shepsle and Weingast call 
'high-demanders'. However, in the EU Council of Ministers such sectoral wishes for increased redistribution might be easily frustrated given the qualified majority threshold. This increases the tendency of the frustrated governments to signal their opposition to a certain legislative outcome back home. The executives rely on this reversed two-level game logic to prevent that the powerful domestic lobbies withdraw their support.

H3: Member States that are high-demanders or high-receivers in policy areas with a high redistributive potential are more likely to oppose legislative proposals.

The Council does not possess clear redistributive power in environmental affairs. However, the regulatory competency of the EU reverberates in this domain so that both the electorates and interest groups should become active. We argue, based on Olson (1982), that the financial concerns of interest groups matter more than the concerns of the citizens over climate change or environmental degradation. Thus, one could expect that governments that have already invested in protecting the environment and want to protect the interests of their median voters make their voices more often heard in environmental policy in order to signal that they care. However, interest groups might work hard against the attempts of some Member States to raise the costs of their rivals by increasing the standards of environmental regulation (Vaubel, 2006). As the Council deliberations only seldom find coverage in national media in contrast to national legislative deliberations, we have to expect that the second argument holds. Governments would rather respond to powerful economic business interests than citizen concerns and cast negative votes if their adaptation costs of their economies to a new environmental standard are comparatively large.

H4: In regulatory policies, Member States with large adaptation costs are more likely to object to legislation at the EU level.

\section{Proposal-Level Influences and Partisanship}

Our theoretical argument that links structural factors to the voting records does not preclude the possibility that ideological preferences influence decision-making behaviour. In fact, we will control for several partisanship variables such as governments' left-right position and the pro EU/anti-EU cleavage as well as their electorates' positions. Many studies have shown that these are the relevant conflict dimensions of the parties and electorates on EU policy-making (Gabel and Anderson, 2002; Manow and Döring, 2008). Ideally, we would like to have information about partisanship and structural factors at the level of each individual proposal. Such a disaggregation is not feasible as it would require the identification of the relevant ideological dimensions of conflict and of the relevant economic and social interests for each proposal. We examine whether two government partisanship measures (attitude towards increasing taxes/lowering public spending and towards environmental protection) influence the chance of a negative vote in the two related policy domains of economic affairs and environmental policy-making. ${ }^{5}$

The literature on EU legislation also suggests some factors at the proposal level that could affect government voting. Holding the Presidency may benefit a Member State via agenda-setting (Steunenberg and Selck, 2006) such that opposition is often not necessary

\footnotetext{
${ }^{5}$ No corresponding encompassing positional information for all government parties between 2004 and 2009 was available in the policy domains of agriculture and fisheries.
} 
for the incumbent of this crucial position. We will accordingly test whether occupying the Presidency decreases the chance that a Member State rejects a piece of legislation. Opposition to a legislative proposal is possible under both qualified majority and unanimity. In a unanimous decision, a government can abstain without blocking the success of the vote. We believe that the costs of opposition are larger under unanimity than under qualified majority voting and therefore expect a higher chance that a government opposes a piece of legislation under the latter rule. Similarly, states face lower reputational losses for being on the wrong side if other Member States join them in the coalition of naysayers. As states want to avoid finding themselves in the role of the permanent Council maverick following a cavalier seul strategy out of principle in every decision-making context, they try to build coalitions of naysayers. We will control at the proposal level whether the presence of other opposing voices increases the chance of an abstention or 'no' vote.

The relationship between the governments and the Commissioners of the same Member States is a tenuous one. While Commissioners are obliged to declare that they will not follow any instructions, 'their' Member States are free to accept or reject proposals for which the 'national' Commissioner was responsible. We expect that there is an underlying solidarity and that the Member States are less likely to oppose proposals from such a Commissioner - not least because they have nominated this person for a seat in the Commission in the first place (Wonka, 2007).

\section{Research Design}

To investigate the influence of various structural variables on the risk of a Member State rejection or abstention, we use multilevel logistic regression models (for example, Rabe-Hesketh and Skrondal, 2008). This approach suggests, in line with our model, that information from the higher level (Member States) and the lower level (proposal characteristics) jointly influence the risk of an opposing vote in the Council.

Our Council voting data are based on information released by the Council Secretariat on the Council website. We employ the 'Monthly Summary of Council Acts', which lists, for all definitive legislative decisions, which Member States voted 'no' or abstained. The time period for the analysis is 1 May 2004 to 30 November 2009. We do not expect the voting data to be biased due to enlargement since several studies have shown the impact of Eastern enlargement on voting to be small (Hagemann, 2008; Hagemann and De Clerck-Sachsse, 2007a; Plechanovová, 2011; Zimmer et al., 2005).

During this time, the Council decided on a total of 960 legislative acts. Of these, 156 (16 per cent) were contested - that is, at least one Member State voted against the majority or abstained. This demonstrates that the majority of decisions in the Council is taken in the absence of explicit opposition, which does not necessarily imply agreement but may also mean that a government did not want to have its opposition identified (Novak, 2013).

The number of contested decisions in the examined policy areas varies between 60 in agriculture, 46 in the domain of economic policy, 17 in environmental politics and 16 in fisheries. The policy sector classification is derived from the Council Secretariat database. The basis for the subject matter coding was the database of all definitive legislative acts. We have added all the subjects mentioned for a specific legislative act to the data set. The number of such references varied considerably, with a maximum of 20 policy links, though most of the documents only list 2-4 subjects. Given this multidimensionality, we 
classified some of the decisions into multiple policy areas. The biggest overlap occurred between agricultural and economic policy-making: 10 of the 156 proposals with at least one opposing vote are classified as both agriculture and economic policy-making. The outcome variable is coded ' 1 ' if a Member State voted 'no' or abstained when a proposal was decided upon, and ' 0 ' otherwise.

To measure the explanatory variables, we used following indicators: the percentage of employment in the agriculture and service sectors and the total fishery production in a country to account for the specific interests of these sectors. Central government debt is used as a rather rough proxy for the financial interests of a country. The unemployment rate and the rigidity of employment index (World Bank, 2007) ${ }^{6}$ are both employed to account for the present state of the economy of a Member State. We employ SOx emissions per capita as operationalization of the environmental interests of a government since sulphur oxides are produced by human activity, subject to government regulations and recognized as a crucial environmental indicator and criteria pollutant by the World Bank (Bernauer and Koubi, 2009). Economic strength is accounted for with the gross domestic product per capita, and we use the ratio of annual EU spending in a country to the annual contribution from the state to account for the budgetary profile of a state.

The partisan orientation of the 93 different government coalitions in the period 2004-9 was calculated for the time point when a proposal was adopted in the Council. Relying on the ParlGov (Döring and Manow, 2013) database we used the left-right orientation, the pro/anti EU integration, the environment and public spending position of the government parties, weighed by the individual strength of the different coalition members. As the governments might also make their decision dependent on the attitudes of their electorates (Spendzharova, 2011), we controlled for both the left-right and the pro-anti EU attitudes of the citizens with Eurobarometer data. To gauge the effect of attitudes towards the EU, we employed the percentage of people responding that the EU is a good thing in their respective country for each half-year period between 2004 and 2009. Furthermore, the effect of additional domestic interests or institutional blockades is operationalized with the veto player index (Armingeon et al., 2009; Hug and Tsebelis, 2002). We also tried to measure institutional factors more elaborately with a measure of the power of the European Affairs committees in the national parliaments based on Maurer and Wessels (2001), Raunio (2005) and Winzen (2012). This more precise measure for parliamentary power in EU affairs, as well as the cabinet power index by Depauw and Martin (2009) did not yield better results so we decided to use the more commonly used veto player index instead.

Our analysis controls for the voting procedure and the Presidency with dummy variables. The possible link between a Commissioner and his/her national government is similarly operationalized through a dichotomous indicator. We obtained this information from the European Union Legislative Output Data Set (Leuffen and Hertz, 2011). Since the costs of voting against the majority are substantially reduced if other states oppose a particular proposal, we control for the number of opposing votes at the proposal level. Table A-1 in the web appendix ${ }^{7}$ summarizes the operationalization of the explanatory variables.

\footnotetext{
${ }^{6}$ The rigidity of employment index measures the regulation of employment - specifically the obstacles in the hiring and firing of workers and the rigidity of working hours. The index ranges from 0 to 100, with higher values indicating more rigid regulations.

${ }^{7}$ Please find the tables of the web appendix on the webpage of this journal.
} 


\section{Results}

In accordance with the theoretical argument, we test our hypotheses on the structural determinants of Council voting in two related steps. First, we examine across all proposals whether socioeconomic characteristics or various partisanship variables influence the tendency to cast a 'no' vote. Second, we evaluate our key argument at a lower level of aggregation through a more detailed analysis of the four policy sectors.

The risk of a 'no' vote or an abstention varies between legislative domains and the aggregate ranking of a country in the list of naysayers does not necessarily correspond to its place in the disaggregated lists. ${ }^{8}$ In the sum of all contested proposals, the 'northern' Member States top the listing. The United Kingdom most frequently says 'no' or abstains from voting, followed closely by Denmark and Germany. Slovenia, Bulgaria and Hungary are the Member States who most often go along with the majority, closely followed by Romania, Cyprus, Luxembourg and Ireland. In the four scrutinized policy fields, Denmark is most often among the frequent naysayers. This maverick tendency is most pronounced in the domain of agriculture in which the Scandinavian Member State contested 9 per cent of all decisions. It is joined in its role as a critical Member State in the domain of fisheries by Poland and its two Baltic neighbours, Lithuania and Estonia. In economic affairs, Germany, Austria, Sweden, the United Kingdom and Malta are the most adamant opposing voices. In the field of environmental decision-making, the group of top contesters consists of an interesting group including Malta, Austria, Italy, Greece, Spain and, again, Denmark. While the Scandinavian state might prefer more stringent environmental regulation than the one proposed by the Commission, the southern Member States most likely prefer more lenient rules.

Governments that vote 'no' or abstain in the final decision-making stage are fully aware that they cannot block the legislation; however they still want to signal to their colleagues in the Council or to their domestic constituency that they do not support a certain piece of legislation. This might be used to demand concessions in future negotiations or it might be a face-saving exercise with the message that a government fought hard, but was unable to overcome an overwhelming majority. Although rejections are most often purely symbolical, there might be still systematic reasons for the differing propensity of states to signal their discontent.

Table 1 introduces eight models through which we explain the propensity of individual Member States to vote 'no' or to abstain. ${ }^{9}$ While the sectoral, structural and redistributive models try to take the 'objective' foundations of EU legislation into account, the institutional and ideological models consider the possible impact of partisanship and domestic institutions. Partisanship is investigated in all eight models to see whether it adds explanatory power. We calculate two regressions for each model. While the first estimation only considers country-level influences, the second one also takes proposal characteristics into account. All regressions in Table 1 refer to the entire set of legislative proposals under examination.

The first model examines the influence that economic sectors exert on Council voting. We use the percentage employed in the first and the third sector as proxies for the power

\footnotetext{
${ }^{8}$ See Table A-2 in the web appendix.

${ }^{9}$ Based on the likelihood ratio test, we can reject the null hypothesis that there is no random intercept in the model and that there is no need for a multilevel analysis for all models under consideration.
} 


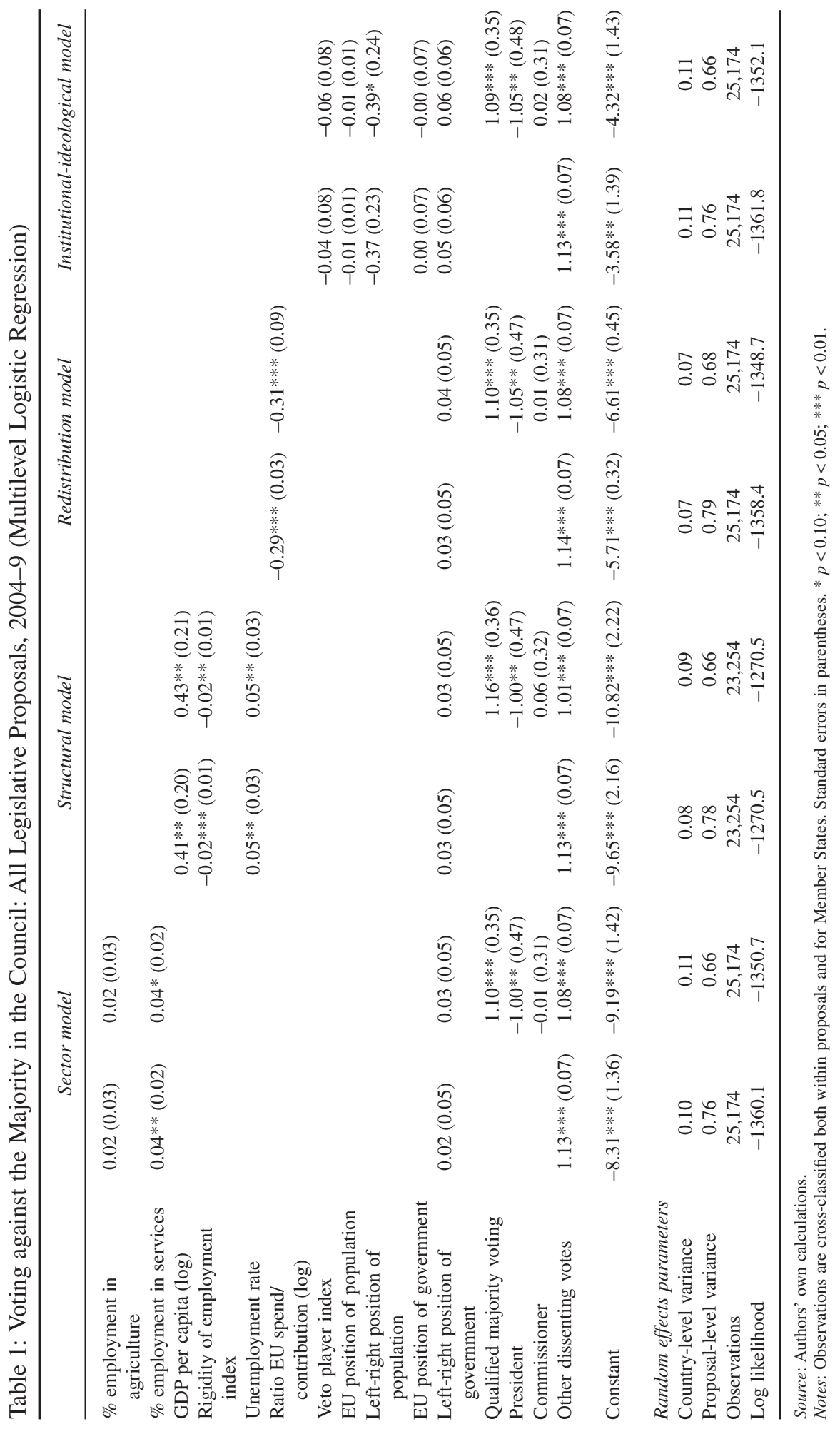


of the sectoral lobbies. Both models establish that countries with a strong service industry are more likely to cast an opposing vote in the Council. The chance of rejecting is five times higher when comparing the Member State with the smallest third sector to the one with the largest. We illustrate this effect in Figure 1.

The structural model analyzes the effects of general characteristics of the Member State economy on government behaviour in the Council. All three indicators influence the risk of opposition in the expected direction (GDP per capita, rigidity of employment, unemployment). As expected, increased economic development goes hand in hand with an increased tendency to oppose EU legislation. This relationship demonstrates in line with our expectations that the culture of consensus only holds in some context. Hence, rich Member States tolerate the redistributive means that are used to compensate the

Figure 1: Estimated Probability of Dissenting Votes by Member States by Selected Explanatory Variables

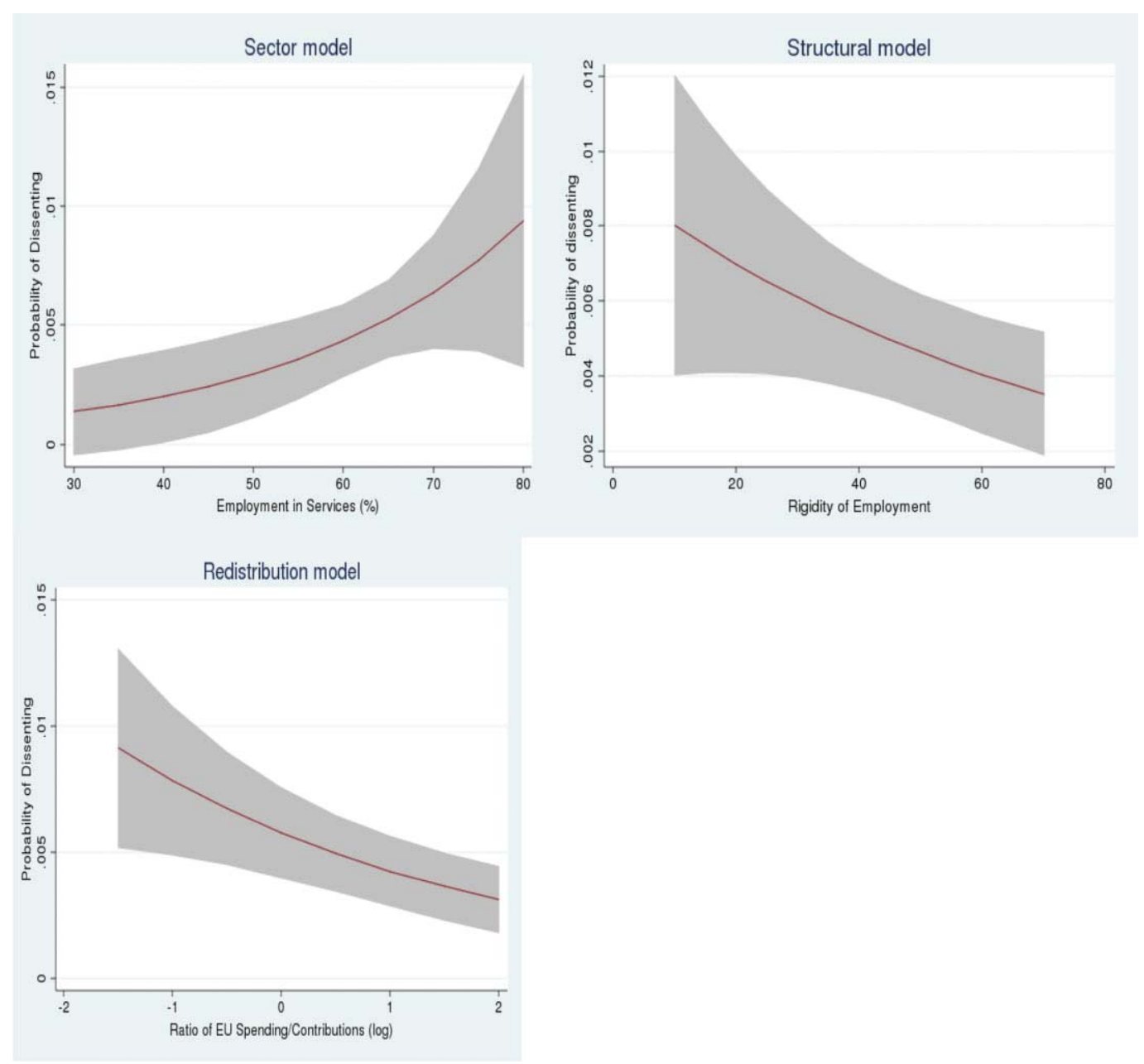

Source: Authors' own calculations.

Notes: Confidence intervals (95 per cent) in gray. See Table 1 for variables. 
economically poorer Member States for their willingness to support the general integration project only up to a certain limit. In some instances, the richer Member States want to signal to their domestic constituents that they have tried to defend their interests by registering a 'no' vote or abstention. The significant coefficient of the rigidity of employment index indicates that countries with more rigid labour markets vote less often against the majority. This indicates, in our view, that the governments of states exhibiting this feature generally favour additional regulation more than more liberally oriented countries. Unemployment, by contrast, exerts a positive and significant relationship. We suspect that governments in countries exposed to economic stress have a more pronounced tendency to signal to their voters that they are reluctant to accept further EU legislation with its often redistributive effects.

We also find support for the second hypothesis according to which the budgetary status of a Member State affects Council legislative behaviour. The redistributive model demonstrates that EU beneficiaries are less likely to vote against the majority. Figure 1 shows that the probability of voting against the Council majority drops to a third when moving from the highest net contributor to the country benefitting the most from the EU budget.

The impact of the socioeconomic structure does not necessarily impinge on the ability of institutional and ideological variables to affect the risk of a 'no' vote. However, neither the veto player variable nor the different ideological variables in any of the models exert any systematic influence on the behaviour of governments in the Council. This finding is confirmed by our additional analyses (not displayed here), which demonstrated that a government's likelihood to oppose EU legislation did not change after a government turnover. We also did not find any support for the possibly curvilinear relationship between ideology and voting behaviour in the Council. Centrist governments are usually more integration-prone than more extremist governments (Manow and Döring, 2008). Estimations reported in the web appendix demonstrate that such a centrist position does not render countries more prone to voting with the Council majority.

Unsurprisingly, proposal-level characteristics systematically influence Member State voting. Governments are more likely to vote 'no' or to abstain when decisions are made with the qualified majority rule instead of the unanimity rule. Our results suggest that a negative vote under a qualified majority threshold is less costly than even 'constructive' opposition with abstention under unanimity.

The significant and negative effect of the Presidency variable indicates that countries in charge of the rotating executive position pronouncedly go along with the Council majority. This finding could lend indirect support to earlier studies showing how governments use the 'power of the chair' to bend the final outcome of a legislative process in their preferred direction (Schalk et al., 2007; Warntjen, 2008). Having realized its position already in the compromise, a Presidency does not need to voice opposition at the end of the decision-making process. It could also be an indication that Presidencies take their task to broker compromises seriously so that they do not oppose proposals they have helped to bring to a conclusion.

Member States do not express any special sympathy towards proposals that have been prepared by a Commissioner representing their country. The lack of relationship between Commissioner's nationality and voting behaviour in the Council frustrates the hopes of the nominating governments, which frequently choose candidates who share their ideological preference (Wonka, 2007). This non-result might also indicate that Commissioners 
are largely unable to leave their ideological or national marks on legislative proposals. As countries become more inclined to vote against a proposal if there are already other opponents, we might rather suspect that intergovernmental haggling and coalitionbuilding dominates the decision-making processes.

To complete our picture of Council decision-making, we move to the analysis of individual sectors. Table 2 presents regression results for the four policy areas under consideration. All models control for the extent to which a country benefits from the EU budget, which reduces the inclination to oppose EU legislation in all policy fields with the exception of the fisheries. This lack of influence may be due to the fact that many of the politically most contentious decisions in this field are regulatory - that is, they are related to fishing quotas. In general, however, our results support the conjecture that interest groups try to capture policy domains with a large redistributive potential.

The results obtained for the agriculture model confirm that countries with a less efficient agricultural industry, such as Estonia, Latvia, and Poland, signal their protest more often to their domestic stakeholders than Member States that do not depend as much on subsidies. We illustrate the magnitudes of the effects of the results in Figure 2. For the fishery sector, we found a small, significant effect of the size of fishery production. The Member States with the biggest fisheries sectors are over than four times more likely to voice dissent in the Council in fisheries matters than countries in which fishing practically does not exist as an economic industry. In both the agriculture and the fishery models, the left-right orientation of the government does not influence government voting behaviour.

The log of SOx emissions per capita increases the chance of an opposing vote. We interpret this in line with our last hypothesis as an attempt of the governments with high adaptation costs in the environmental domain to avoid further regulation at the EU level. Although we have used a rather direct ideological measure to estimate the impact of the environmental orientation of the governments, we were unable to find any influence for this variable. A similar result emerged for the decisions made in economic affairs. As the less affluent states tend to vote against the majority, Member States with a 'bad' status quo in regulatory policies tend to object more often in the Council than countries with lower costs of regulatory reform. The attitude of a government towards public spending versus lowering taxes does not help predict why some states voice their opinion on the proposals in this category.

The analysis demonstrates that we can understand intergovernmental decision-making much better if we add structural factors in our explanatory repertoire. As we have demonstrated, economic and financial interests of important domestic stakeholders determine to a considerable extent whether a national government wants to publicly signal its discontent with the winning majority.

\section{Conclusions}

One of the key controversies in political science is whether ideology or economic and social interests influence public decisions. This article adds to the growing evidence (Aksoy, 2010; Hosli et al., 2011; Kauppi and Widgrén, 2004; Zimmer et al., 2005) that redistributive conflicts considerably shape decision-making in the EU in general and in its most important legislative actor - the Council - in particular. Our empirical analyses demonstrate that relatively rough socioeconomic indicators determine the voting 


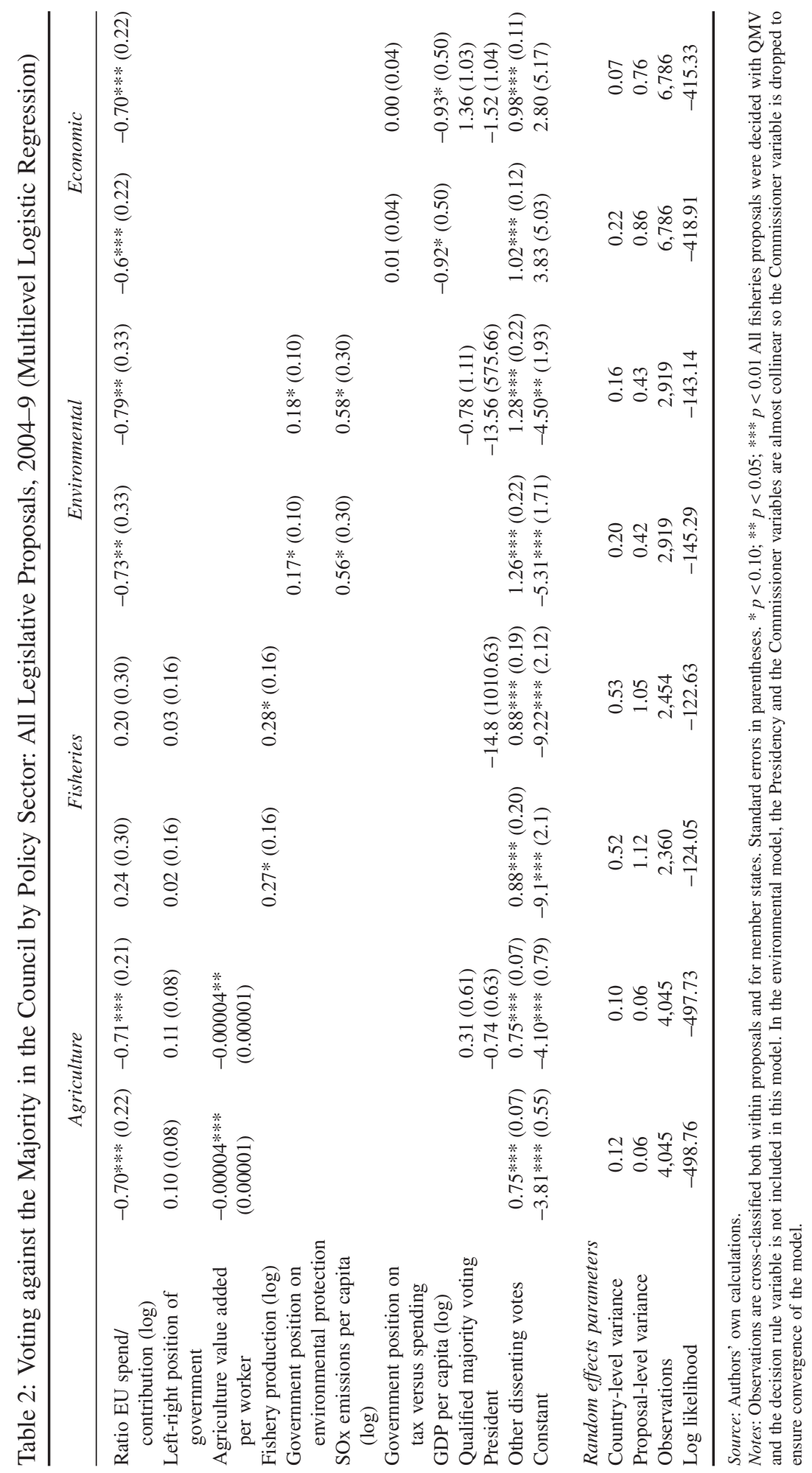


Figure 2: Estimated Probability of Dissenting Votes by Member States by Policy Sector
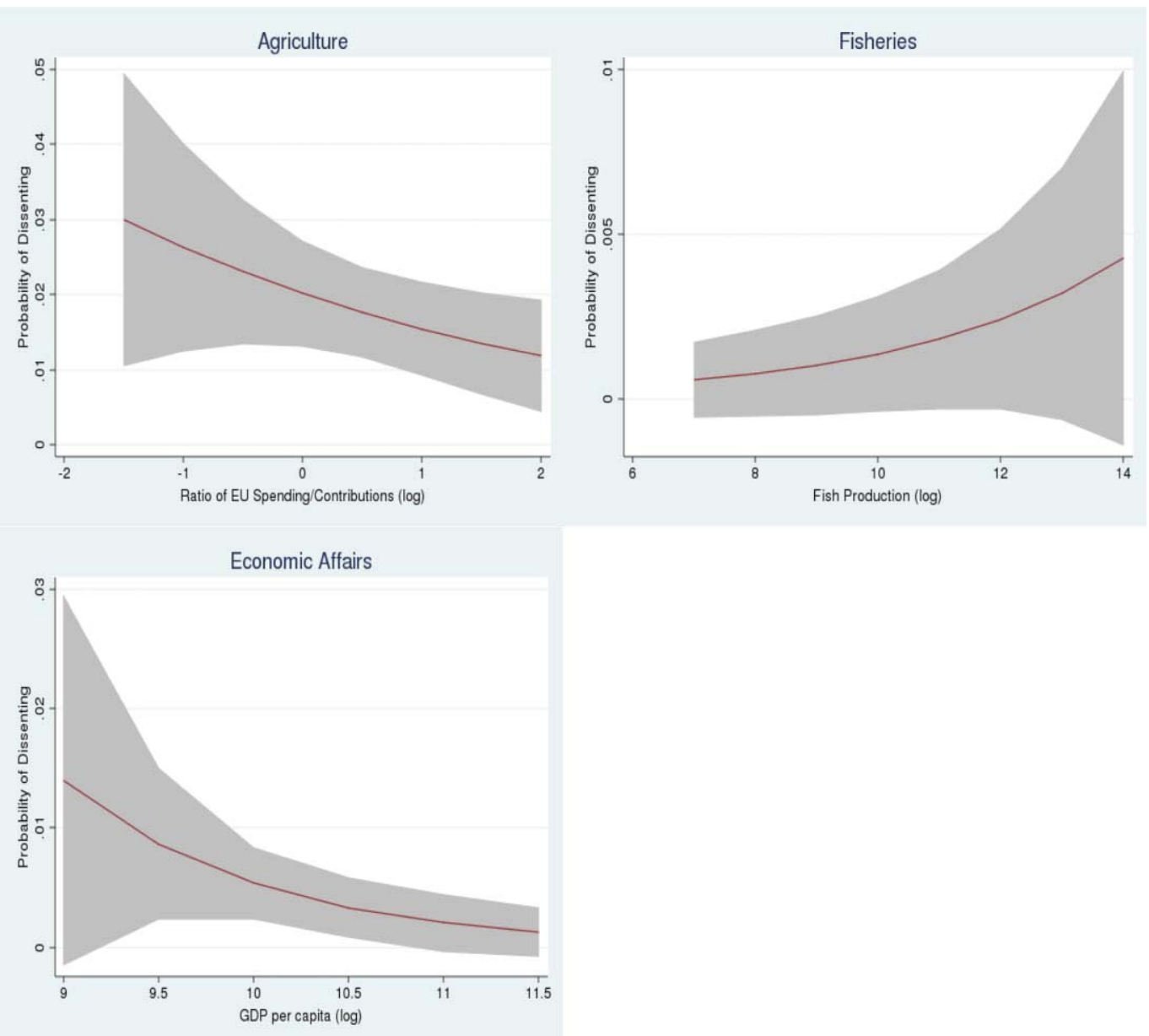

Source: Authors' own calculations.

Notes: Confidence intervals (95 per cent) in gray. See Table 2 for variables.

behaviour of the Member State governments considerably. This suggests that conflict among Member States has 'objective' foundations and, in line with Peltzman's (1984) classic article, that ideological positions also mask economic interests in the EU to some extent.

Our analysis suggests that governments respond to both the general interests of the population and the wishes of strong national lobbies such as the agricultural industry. As the Council of Ministers mainly uses subsidies to appease the structurally weaker Member States and regions, net EU budget contributors are more likely to oppose EU legislation than net beneficiaries. Economically strong Member States generally continue to support the integration process as they reap considerable non-legislative benefits from deepening European integration. This compensatory logic holds true in the aggregate, but also for the explanation of the voting patterns in the specialized Councils that we examined. It is quite 
possible that economic interests would be much more obvious if we were able to look at proposals that never reach the ministers' negotiation table in the Council because they lack the necessary support to proceed to this stage of the decision-making process. We do not have systematic knowledge about these unfinished legislative projects so as to test this hypothesis.

Further studies would benefit from an analysis of additional policy areas such as justice and home affairs or social affairs where the attractiveness of a Member State for migrants or national budgetary pressure could be important drivers for Council behaviour. Although partisanship does not systemically influence voting in the Council, ideology should not be dismissed as a potential explanation of Council deliberations. This holds particularly true in the post-Lisbon period where all formal decisions are made in public. Governments will have fewer chances to redistribute income to special interests and unproductive sectors when public scrutiny becomes more intensive. However, the lack of evidence found for partisanship explanations simultaneously implies that we should be careful in proclaiming that the EU has become a relatively normal polity and that there is a tendency towards a unifying political space across all EU institutions. While it is perfectly plausible that the left-right conflict overshadows interactions in the European Parliament, voting in the Council is largely dominated by the structural cleavages between rich and poor Member States and thus a division that will become more pronounced in times of economic stress and hardship.

Correspondence:

Stefanie Bailer

Center for Comparative and International Studies

ETH Zurich

Haldeneggsteig 4

8092 Zurich

Switzerland

email bailers@ethz.ch

\section{References}

Aksoy, D. (2010) 'Who Gets What, When and How Revisited: Voting and Proposal Powers in the Allocation of the EU budget'. European Union Politics, Vol. 11, No. 2, pp. 171-94.

Aksoy, D. (2012) 'Institutional Arrangements and Logrolling: Evidence from the European Union'. American Journal of Political Science, Vol. 56, No. 3, pp. 538-52.

Armingeon, K., Careja, R., Potolidis, P., Gerber, M. and Leimgruber, P. (2009) Comparative Political Data Set III, 1990-2007 (Berne: Institute of Political Science, University of Berne).

Bailer, S. (2011) 'Structural, Domestic and Strategic Interests in the European Union: Negotiation Positions in the Council of Ministers'. Negotiation Journal, Vol. 27, No. 4, pp. 447-75.

Baron, D.P. (1991) 'Majoritarian Incentives, Pork Barrel Programs and Procedural Control'. American Journal of Political Science, Vol. 35, No. 1, pp. 57-90.

Bernauer, T. and Koubi, V. (2009) 'Effects of Political Institutions on Air Quality'. Ecological Economics, Vol. 68, No. 5, pp. 1355-65.

Carrubba, C.J. (1997) 'Net Financial Transfers in the European Union: Who Gets What and Why?'. Journal of Politics, Vol. 59, No. 2, pp. 469-96.

Crombez, C. (2000) 'Spatial Models of Logrolling in the European Union'. European Journal of Political Economy, Vol. 16, No. 4, pp. 707-37. 
Depauw, S. and Martin, S. (2009) 'Legislative Party Discipline and Cohesion in Comparative Perspective'. In Giannetti, D. and Benoit, K. (eds) Intra-Party Politics and Coalition Governments (New York: Routledge).

Döring, H. and Manow, P. (2013) Parliament and Government Composition Database (ParlGov): An Infrastructure for Empirical Information on Political Institutions, Version 10/02. Available at: «http://www.parlgov.org/».

Elgström, O., Bjurulf, B., Johansson, J. and Sannerstedt, A. (2002) 'Coalitions in European Union Negotiations'. Scandinavian Political Studies, Vol. 24, No. 2, pp. 111-28.

Franchino, F. and Rahming, A. (2003) 'Biased Ministers, Inefficiency and Control in Distributive Policies'. European Union Politics, Vol. 4, No. 1, pp. 11-36.

Gabel, M.J. and Anderson, C.J. (2002) 'The Structure of Citizen Attitudes and the European Political Space'. Comparative Political Studies, Vol. 35, No. 8, pp. 893-913.

Grossman, G.M. and Helpman, E. (1996) 'Electoral Competition and Special Interest Politics'. Review of Economic Studies, Vol. 63, pp. 265-86.

Hagemann, S. (2007) 'Applying Ideal Point Estimation to the Council of Ministers'. European Union Politics, Vol. 8, No. 2, pp. 279-96.

Hagemann, S. (2008) 'Voting, Statements and Coalition-Building in the Council from 1999-2006'. In Naurin, D. and Wallace, H. (eds) Unveiling the Council of the European Union: Games Governments Play in Brussels (Basingstoke: Palgrave Macmillan).

Hagemann, S. and De Clerck-Sachsse, J. (2007a) 'Decision-Making in the Enlarged Council of Ministers: Evaluating the Facts'. Policy Brief 119 (Brussels: Centre for Economic Policy Studies).

Hagemann, S. and De Clerck-Sachsse, J. (2007b) 'Old Rules, New Game: Decision-Making in the Council of Ministers after the 2004 Enlargement'. Special Report (Brussels: Centre for Economic Policy Studies).

Hagemann, S. and Høyland, B. (2008) 'Parties in the Council?'. Journal of European Public Policy, Vol. 15, No. 8, pp. 1205-21.

Heisenberg, D. (2005) 'The Institution of "Consensus" in the European Union: Formal versus Informal Decision-Making in the Council'. European Journal of Political Research, Vol. 44, pp. 65-90.

Hillman, A.L. (1989) The Political Economy of Protection (London: Routledge).

Hosli, M.O., Mattila, M. and Uriot, M. (2011) 'Voting in the Council of the European Union after the 2004 Enlargement: A Comparison of Old and New Member States'. JCMS, Vol. 49, No. 6, pp. $1249-70$.

Hug, S. and Tsebelis, G. (2002) 'Veto Players and Referendums around the World'. Journal of Theoretical Politics, Vol. 14, No. 4, pp. 465-515.

Kaeding, M. and Selck, T. (2005) 'Mapping Out Political Europe: Coalition Patterns in EU Decision-Making'. International Political Science Review, Vol. 26, No. 3, pp. 271-90.

Kandogan, Y. (2000) 'Political Economy of Eastern Enlargement of the European Union: Budgetary Costs and Reforms in Voting Rules'. European Journal of Political Economy, Vol. 16, No. 4, pp. 685-705.

Kau, J.B. and Rubin, P.H. (1979) 'Self-Interest, Ideology and Logrolling in Congressional Voting'. Journal of Law and Economics, Vol. 22, No. 2, pp. 365-84.

Kauppi, H. and Widgrén, M. (2004) 'What Determines EU Decision Making? Needs, Power or Both?'. Economic Policy, Vol. 19, No. 39, pp. 221-66.

König, T. and Junge, D. (2009) 'Why Don't Veto Players Use Their Power?'. European Union Politics, Vol. 10, No. 4, pp. 507-34.

Laswell, H.D. (1936) Politics: Who Gets What, When, How (New York: Whittlesey House). 
Lequesne, C. (2000) 'Quota Hopping: The Common Fisheries Policy between States and Markets'. JCMS, Vol. 38, No. 5, pp. 779-93.

Leuffen, D. and Hertz, R. (2011) European Union Legislative Output Data (Zurich: ETH Zurich).

Magee, S., Brock, W. and Young, L. (1989) Black Hole Tariffs and Endogenous Policy Theory: Political Economy in General Equilibrium (Cambridge: Cambridge University Press).

Manow, P. and Döring, H. (2008) 'Electoral and Mechanical Causes of Divided Government in the European Union'. Comparative Political Studies, Vol. 41, No. 10, pp. 1349-70.

Mattila, M. (2009) 'Roll Call Analysis of Voting in the European Union Council of Ministers after the 2004 Enlargement'. European Journal of Political Research, Vol. 48, No. 6, pp. 840-57.

Maurer, A. and Wessels, W. (2001) National Parliaments on Their Ways to Europe: Losers or Latecomers? (Baden-Baden: Nomos Verlagsgesellschaft).

Moravcsik, A. (1998) The Choice for Europe (Ithaca, NY: Cornell University Press).

Naurin, D. and Lindahl, R. (2008) 'East-North-South: Coalition-Building in the Council before and after Enlargement'. In Naurin, D. and Wallace, H. (eds) Unveiling the Council of the European Union: Games Governments Play in Brussels (Basingstoke: Palgrave Macmillan).

Novak, S. (2013) 'The Silence of Ministers: Consensus and Blame Avoidance in the Council of the European Union'. JCMS, Vol. 51, No. 6, pp. 1091-107.

Olson, M. (1965) The Logic of Collective Action: Public Goods and the Theory of Groups (Cambridge, MA: Harvard University Press).

Olson, M. (1982) The Rise and Decline of Nations: Economic Growth, Stagflation and Social Rigidities (New Haven, CT: Yale University Press).

Peltzman, S. (1976) 'Toward a More General Theory of Regulation'. Journal of Law and Economics, Vol. 19, pp. 211-40.

Peltzman, S. (1984) 'Constituent Interest and Congressional Voting'. Journal of Law and Economics, Vol. 27, pp. 181-210.

Plechanovová, B. (2011) 'The EU Council Enlarged: North-South-East or Core-Periphery?'. European Union Politics, Vol. 12, No. 1, pp. 87-106.

Rabe-Hesketh, S. and Skrondal, A. (2008) Multilevel and Longitudinal Modeling Using Stata (College Station, TX: Stata Press).

Raunio, T. (2005) 'Holding Governments Accountable in European Affairs: Explaining CrossNational Variation'. Journal of Legislative Studies, Vol. 11, No. 3, pp. 319-42.

Schalk, J., Torenvlied, R., Weesie, J. and Stokman, F.N. (2007) 'The Power of the Presidency in EU Council Decision-Making'. European Union Politics, Vol. 8, No. 2, pp. 229-50.

Schneider, G. (2008) 'Neither Bismarck nor Goethe: On the Link Between Theory and Empirics in Council Decision Making Studies'. In Naurin, D. and Wallace, H. (eds) Unveiling the Council of the European Union: Games Governments Play in Brussels (Basingstoke: Palgrave Macmillan).

Schneider, G., Finke, D. and Baltz, K. (2007) 'With a Little Help from the State: Interest Intermediation in the Domestic Pre-Negotiations of EU Legislation'. Journal of European Public Policy, Vol. 14, No. 3, pp. 444-59.

Schuknecht, L. (1992) Trade Protection in the European Community (London: Routledge).

Shepsle, K.A. and Weingast, B.R. (1981) 'Structure-Induced Equilibrium and Legislative Choice'. Public Choice, Vol. 37, No. 3, pp. 503-19.

Shepsle, K.A. and Weingast, B.R. (1987) 'The Institutional Foundations of Committee Power'. American Political Science Review, Vol. 81, No. 1, pp. 85-104.

Spendzharova, A. (2011) 'Is More "Brussels" the Solution? New European Union Member States' Preferences about the European Financial Architecture'. JCMS, Vol. 50, No. 2, pp. 315-34.

Steunenberg, B. and Selck, T. (2006) 'Testing Procedural Models of EU Legislative DecisionMaking'. In Thomson, R., Stokman, F.N., Achen, C. and König, T. (eds) The European Union 
Decides: Political Economy of Institutions and Decisions (Cambridge: Cambridge University Press).

Stigler, G. (1971) 'The Theory of Economic Regulation'. Bell Journal of Economics and Management, Vol. 2, pp. 3-21.

Stratmann, T. and Baur, M. (2002) 'Plurality Rule, Proportional Representation and the German Bundestag: How Incentives to Pork-Barrel Differ across Electoral Systems'. American Journal of Political Science, Vol. 46, No. 3, pp. 506-14.

Thomson, R. (2009) 'Actor Alignments in the European Union before and after Enlargement'. European Journal of Political Research, Vol. 48, No. 6, pp. 756-81.

Thomson, R., Boerefijn, J. and Stokman, F.N. (2004) 'Actor Alignments in European Union Decision Making'. European Journal of Political Research, Vol. 43, pp. 237-61.

Vaubel, R. (2006) 'Principal-Agent Problems in International Organizations'. Review of International Organizations, Vol. 1, No. 1, pp. 125-38.

Veen, T. (2011) 'The Dimensionality and Nature of Conflict in European Union Politics: On the Characteristics of Intergovernmental Decision-Making'. European Union Politics, Vol. 12, No. 1 , pp. $65-86$.

Warntjen, A. (2008) 'The Council Presidency'. European Union Politics, Vol. 9, No. 3, pp. 315-38.

Winzen, T. (2012) 'National Parliamentary Control of European Union Affairs: A Cross-National and Longitudinal Comparison'. West European Politics, Vol. 35, No. 3, pp. 657-72.

Wonka, A. (2007) 'Technocratic and Independent? The Appointment of European Commissioners and Its Policy Implications'. Journal of European Public Policy, Vol. 14, No. 2, pp. 169-89.

World Bank (2007) World Development Indicators (WDI) 2007 Database (Geneva: World Bank).

Zimmer, C., Schneider, G. and Dobbins, M. (2005) 'The Contested Council: Conflict Dimensions of Intergovernmental Institution'. Political Studies, Vol. 53, No. 2, pp. 403-22.

\section{Supporting Information}

Additional Supporting Information may be found in the online version of this article at the publisher's web-site:

Table A1: List of Variables used in the analyses

Table A2: Share of contested decisions by member state and by policy sector May 12004 - 31 December 2009 (2007-09 for Bulgaria and Romania)

Table A3: Voting against the majority in the Council. All legislative proposals 2004-09, rare events logistic regression

Table A4: Voting against the majority in the Council by policy sector 2004-09, rare events logistic regression

Table A5: Voting against the majority in the Council. All legislative proposals 2004-09, multilevel logistic regression, ideological variables squared

Table A6: Voting against the majority in the Council by policy sector 2004-09, multilevel logistic regression, ideological variables squared

Table A7: Voting against the majority in the Council by policy sector 2004-09, multilevel logistic regression with interaction effects 